\title{
Expert System With Certainty Factor For Early Diagnosis Of Red Chili Peppers Diseases
}

\author{
Fahrul Agus*1, Hernandha Eka Wulandari ${ }^{2}$, Indah Fitri Astuti ${ }^{3}$ \\ Computer Science Dept., Faculty of CSIT, Mulawarman University \\ Kuaro Street, Gunung Kelua Campus, Mulawarman University Telp. 0541-749343, Samarinda 75123 - \\ Kalimantan Timur - Indonesia \\ E-mail :fahrulagus@unmul.ac.id ${ }^{* 1}$, hernandha@gmail.com ${ }^{2}$, indahfitriastuti@fmipa.unmul.ac.id ${ }^{3}$ \\ *Corresponding author
}

\begin{abstract}
Red chili peppers (Capsicum annuum L.) plants classified as fruit and vegetables spices (herbs), that almost all people consume it for everyday purposes. Not only used for household consumption, but also used in various industries as a raw material. Utilization as raw materials in various industry makes red chili as vegetable crops of high economic value and has a great prospect. But its diseases are complex enough for causing farmers hard to diagnose and resulted in reduced production levels. One solution to this problem is the establishment of an expert system that can help farmers to diagnose major diseases of red pepper plant in a practical and accurate. The purpose of this research is to make the application of expert systems for diagnosing diseases of red chili. This application uses forward chaining to diagnose disease and calculate the value of possibilities with Certainty Factor. This method is to prove whether a fact that certainly would not have been shaped or metrics that are typically used in an expert system. This method is suitable for expert systems to diagnose something uncertain. Certainty Factor expressed confidence in an event or factual hypothesis based on evidence or expert judgment. The results of research is in the form of an expert system application that can diagnose diseases of red pepper plants with enough accuracy and can help in overcoming the problem of crop failure. Based on the data taken from tests performed in this study, the system can diagnose red chili plant disease with high accuracy.
\end{abstract}

Keywords - Forward Chaining, Certainty Factor Method, Expert System, Red Chili Peppers.

\section{INTRODUCTION}

\subsection{Background}

Red chili peppers is one of the strategic commodities in the horticultural sector that the production need to be increased. However, diseases that attack red pepper plants are quite complex, with symptoms of quite a lot of disease and some diseases that have the same symptoms, handling and control of chili diseases that has not been correct, causing farmers difficult to diagnosing red pepper disease and resulted in reduced production level [1-2]. The establishment of expert systems diagnosis of red pepper disease into one of the farmers solution to control the disease that occurs in red chili plants. Certainty Factor is a method to prove whether a fact is definite or uncertain in the form of a metric that usually used in expert systems. Based on the problem to overcome the disease of red pepper plants, it is necessary to build a computerized system that has knowledge such as botanical experts and the system can be a tool in diagnosing the type of disease and provide solutions how to handle and control. Expert System is one area of knowledge that can be a tool in overcoming the problem. 


\section{RESEARCH METHOD AND LITERATURE REVIEW}

2.1 Research Method

Comparing the three previous studies, namely: "Pemodelan Sistem Pakar Diagnosa Penyakit Tanaman Cabai Merah Menggunakan Metode AHP-SAW" [3], "Sistem Pakar Untuk Mendiagnosa Hama dan Penyakit Tanaman Bawang Merah Menggunakan Metode Certainty Factor" [4] and "Sistem Pakar Kerusakan Mesin Jahit Dengan Metode Certainty Factor Berbasis Android" [5].

\subsection{Literature Review}

\subsubsection{Expert System}

The expert system is designed to solve quite complex problems that only experts can solve. The making of an expert system is not to replace the expert himself but can be used as a highly experienced assistant [6-7].

\subsubsection{The Benefit of Expert System}

Many capabilities and benefits provided by Expert System includes:

1. Increase output and productivity, because expert systems can work faster than humans.

2. Improve quality, by giving consistent advice and reducing errors

3. Able to capture very limited expertise.

4. Can operate in different environments and at any time.

5. Expert systems never get bored and tired or sick. The Expert System also consistently looks at all the details and will not miss out on relevant information and potential solutions.

6. Enhance the capability of other computerized systems.

7. System Integration Experts with other computer systems make it more effective, and include more applications.

8. Able to work with incomplete or uncertain information.

9. Unlike conventional computer systems, Expert Systems may work with incomplete information. Users may respond by either "not knowing" or "not sure" to one or more questions during the consultation, and the Expert System will still provide the answer [5].

\subsubsection{The Architecture of Expert System}

Expert systems are structured by two main parts, Environmental Development and Consultancy Environment. Environmental development are used to incorporate expert development into an expert system environment. Consultation environments are used by non-experts to gain expert knowledge and advice. Most current expert systems do not contain a knowledge improvement component [8].

\subsubsection{Development of Expert System}

Developing an expert system can be done in two ways:

1. Build your own components

2. Wearing all the existing components except the contents of the knowledge base. The stages of expert system development are:
1) Problem Selection
2) Knowledge Engineering
3) Participants In The Development Process
4) Knowledge Acquisition 


\subsubsection{Expert System Inference}

The inference engine is a computer program that provides a methodology for reasoning about information that is in the knowledge base and in the workplace to formulate conclusions [9].

Forward Chaining is an inference strategy that begins with a set of facts, new facts obtained by using the rule, where the reasons are used in accordance with the facts, and continue this process until the goal is reached or until no further rule has a reason that corresponds to the fact There are also known facts.

Backward Chaining is the inference strategy obtained to prove a hypothesis with the support of information [5].

\subsubsection{Certainty Factor (CF) Method}

Expert system must be able to work in uncertainty. A number of theories have been found to solve the problem of uncertainty, including classical probability, Bayesian probability, Zadeh's fuzzy theory and Certainty Factor.

Certainty Factor is a method to prove whether a fact is definite or uncertain in the form of a metric usually used in expert system. This method is perfect for expert systems that diagnose something that is not certain [10].

Certainty Factor introduced by Shortliffe Buchanan in the making of MYCIN Certainty Factor (CF) is the value of the clinical parameters given by MYCIN to indicate the magnitude of the trust. Certainty Factor is defined as the equation:

$$
C F(H, E)=M B(H, E)-M D(H, E)
$$

$\mathrm{CF}(\mathrm{H}, \mathrm{E})$ : Certainty Factor of the hypothesis $\mathrm{H}$ influenced by the symptoms $\mathrm{E}$. The magnitude of $\mathrm{CF}$ ranges from -1 to 1 . The value of -1 shows absolute mistrust while the value 1 indicates absolute trust.

$\mathrm{MB}(\mathrm{H}, \mathrm{E})$ : Measures of increased belief (measure of increased belief) on the hypothesis $\mathrm{H}$ is influenced by the symptoms of $E$.

$M D(H, E)$ : Measure of increased disbelief of the hypothesis $H$ influenced by the symptoms of $E$.

The basic form of the Certainty Factor formula, is a rule IF E THEN H as indicated by the equation:

$$
C F(H, e)=C F(E, e) * C F(H, E)
$$

$\mathrm{CF}(\mathrm{H}, \mathrm{e}) \quad$ : Certainty Factor hypotheses that are influenced by the evidence e.

$\mathrm{CF}(\mathrm{E}, \mathrm{e}) \quad$ : Certainty Factor evidence $\mathrm{E}$ influenced by the evidence e.

$\mathrm{CF}(\mathrm{H}, \mathrm{E}) \quad$ : Certainty Factor hypothesis assuming the evidence is known with certainty, e when $\mathrm{CF}(\mathrm{E}, \mathrm{e})=1$

If all the antecedent evidence is known with certainty then the equation will be:

$\mathrm{CF}(\mathrm{E}, \mathrm{e})=\mathrm{CF}(\mathrm{H}, \mathrm{E})$

In the application, $\mathrm{CF}(\mathrm{H}, \mathrm{E})$ is the value of certainty given by the expert to a rule, while $\mathrm{CF}(\mathrm{E}, \mathrm{e})$ is the value of trust given by the user to the phenomenon experienced. For example, here is a rule with CF given by an expert:

IF cough

AND fever

AND headaches

AND sneezing 


\section{THEN influenza, CF: 0.7}

This Certainty Factor method can only process 2 weights in a single calculation. For more than 2 weights, to do the calculation does not matter if the calculated weights are randomized, meaning there is no rule to combine the weights, because for any combination the results will remain the same. For example, to know whether a patient suffering from cough disease or not, judging from the calculation of weight after all the complaints entered and all the weights are calculated using the Certainty Factor method [4-5].

Patients convicted of cough disease are patients who weigh close to +1 with the complaints they have leading to the disease. While patients who weigh close to -1 are patients who are considered not suffering from cough disease, and patients who have the same weight with 0 unknown or unknown diagnosis or can be called with neutral.

The advantages of the Certainty Factor method are:

1. This method is suitable to use in expert systems to measure whether definitive or uncertain in diagnosing illness as an example.

2. Calculations using this method in one count only can process 2 datas only so that the accuracy of data can be maintained.

The lack of the Certainty Factor method are:

1. The general idea of modeling human uncertainty using numerical methods of Certainty Factor is usually debated. Some people will argue that the formula for the above Certainty Factor method has little truth.

2. This method can only process uncertainty / certainty only 2 data only. It needs to be done several times data processing for data more than 2 datas.

\subsection{Red Chili Peppers}

The history of chili was first discovered by Christopher Columbus in 1492 in America. Indigenous Indian tribes of the continent, apparently utilize chili that is estimated to have existed since the year 5000 BC. Chili brought by Columbus home to Europe became a favorite and growing so rapidly. Within 50 years, chillies thrive and chillies have spread to the coasts of Africa, India, the Middle East, the Balkans, Asia and Southern China. This is thanks to the services of very active Portuguese traders. The introduction of chili to India, within half a century Indians were able to develop three subspecies of chili. This makes India the world's chili producer because of more than one million tons of chili every year. From India and the coast of Malabar, chillies spread to Southeast Asia along with Indian merchants with their counterparts in China, Malaysia, Vietnam and Java [11-13].

The red chili is one of the most attractive agricultural commodities. At certain moments, the price can rise many times. At other moments can go down to worthless. This makes red chili cultivation a challenge for farmers. Besides price fluctuations, pepper cultivation is quite vulnerable to weather conditions and pest attacks [3].

\subsubsection{The Main Diseases of Red Chili}

1) Antraknosa. An anthracnose disease in pepper plants is caused by the Colletotrichum capsici fungus, the anthracnose or patek fungus that develops very rapidly when the air humidity is high enough if it is more than $80 \%$ with a temperature of 32 degrees Celsius.

2) Cercospora. This disease is caused by the fungus Cercospora capsici and cause the leaves will experience an unhealthy situation and eventually fall.

3) Fusarium. Fusarium wilt disease is caused by the Fusarium oxysporum fungus. The spread of the fungus Fusarium oxysporum is aided by water, agricultural equipment, and humans.

4) Gemini Virus. The virus is transmitted by the tick of Bemisia tabaci kebul. An adult viruscontaining lice can transmit the virus during its lifetime when it eats healthy plants. 
5) Phytophthora. Disease on red pepper plants is caused by the fungus Phytophthora capsici and Phytophtora infestans. At high moisture levels, eg in the rainy season, the disease develops very quickly. In addition, at a relatively low temperature of 16 to 24 degrees Celsius, also support its development. Disease on red pepper plants is caused by the fungus Phytophthora capsici and Phytophtora infestans. At high moisture levels, eg in the rainy season, the disease develops very quickly. In addition, at a relatively low temperature of 16 to 24 degrees Celsius, also support its development.

6) Mosaic. The cause of mosaic disease is Mosaic Virus (MV). Viruses enter the tissues through the wound and multiply and spread throughout the plant tissues systemically.

\section{RESULT AND DISCUSSION}

3.1 Data Collection

Data collection is done in consultation to get expert data through interviews and supporting data that is references obtained from journals and dissertations.

\subsection{Design Process}

The design process on the diagnosis of red pepper disease is using Certainty Factor (CF) method. The data needed for the diagnosis of red pepper disease is the data of disease symptoms seen in chili.

Design system is the phase that done to design systems both in terms of model and architecture. Steps system works adapted to architecture has been designed. At this stage outline regarding the performance of system is structured, started from the input to output produced. Diagram model design a system can be seen in figure 1 .

\begin{tabular}{|c|c|c|}
\hline Input & Processes & Output \\
\hline $\begin{array}{l}\text { Types of disease } \\
\text { Symptoms of } \\
\text { disease } \\
\text { The cause of } \\
\text { Solution of } \\
\text { handling and } \\
\text { tacling }\end{array}$ & $\begin{array}{l}\text { Tracing expert system } \\
\text { with the forward } \\
\text { chaining and the } \\
\text { calculation with } \\
\text { Certainty Factor ( CF ) }\end{array}$ & $\begin{array}{l}\text { The percentage } \\
\text { based on the } \\
\text { decision made a } \\
\text { disease } \\
\text { experienced in } \\
\text { plants red pepper }\end{array}$ \\
\hline
\end{tabular}

Figure 1. model design expert system the diagnosis plant disease red pepper

In figure 1 shows that design system consisting of three main process:

1. Input

User input data from the disease attack plants red pepper, then before data process to produce values on each symptoms and will be criteria input on the calculation.

2. Processes

Uses the calculations CF to determine the lesson of any criteria made.

3. Output

Output is percentage of diagnose disease in plants red pepper. 


\subsection{System Planning}

The design of expert system of diagnosis of red pepper disease using Certainty Factor (CF) is using Unified Modeling Language (UML) which consists of Use Case Diagram and Activity Diagram to explain the process of designing system design process that has been done such as making use case diagram and activity diagram [14-16].

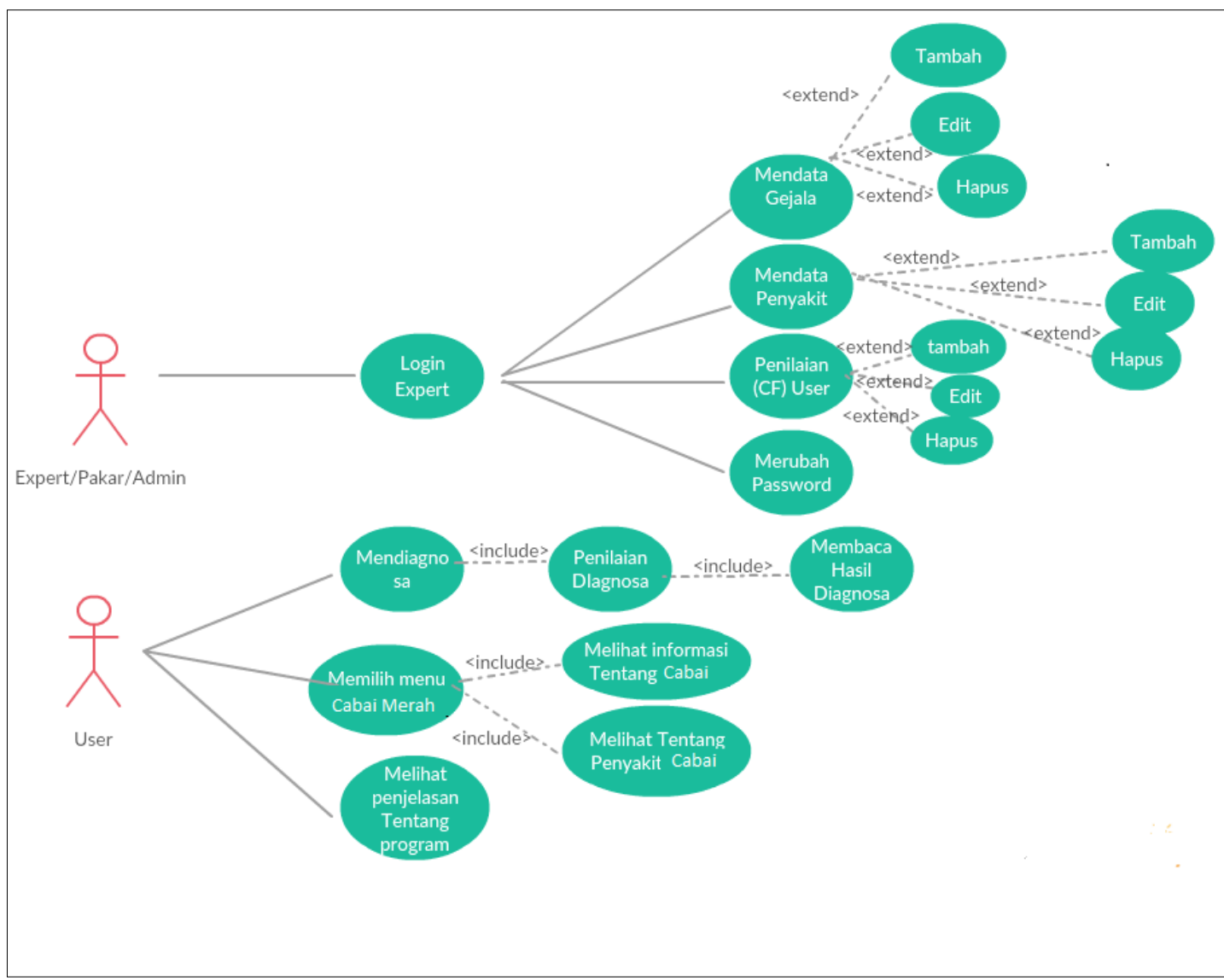

Figure 2. Use case diagram: Expert System With Certainty Factor For Early Diagnosis Of Red Chili Peppers Diseases Uses Case Diagram 


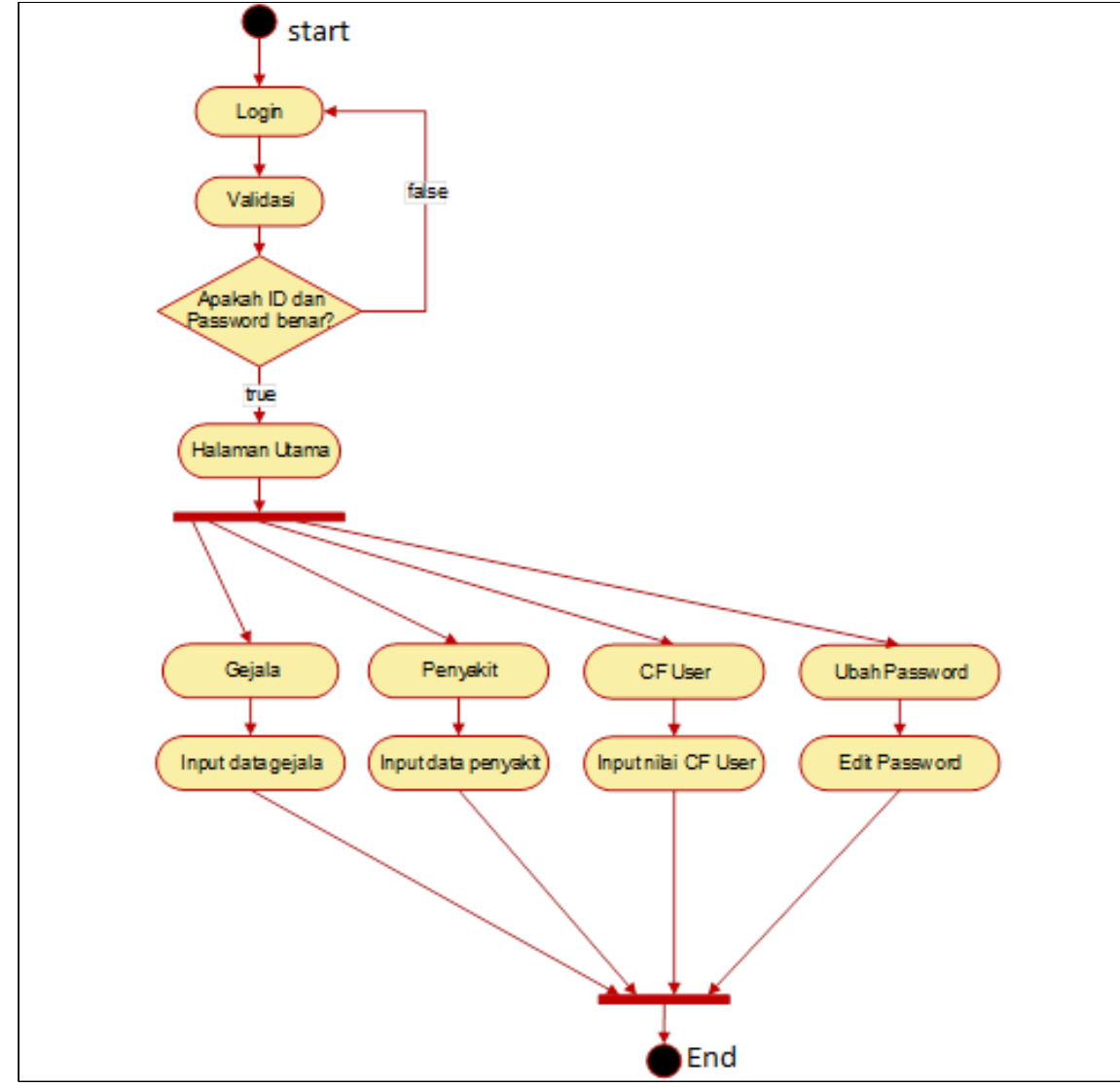

Figure 3. Activity diagram: pert System With Certainty Factor For Early Diagnosis Of Red Chili Peppers Diseases Activity Diagram

\subsection{Database Design}

1. Login

The login table serves to store login data for experts or experts with details in table 1.

Table 1. Login Table

\begin{tabular}{|c|c|c|c|}
\hline Attribute & Type & Size & Description \\
\hline Id & Varchar & 10 & Primary key \\
\hline Pass & Varchar & 10 & - \\
\hline
\end{tabular}

\section{Diseases}

The disease table serves to store the disease type data for the details in Table 2.

Table 2. Disease Table

\begin{tabular}{|c|c|c|c|}
\hline Attribute & Type & Size & Description \\
\hline id_disease & Int & 4 & Disease ID \\
\hline Name & Varchar & 10 & Disease Name \\
\hline $\begin{array}{c}\text { Disease } \\
\text { Information }\end{array}$ & LongText & - & $\begin{array}{c}\text { Disease } \\
\text { Information }\end{array}$ \\
\hline $\begin{array}{c}\text { Cause of } \\
\text { disease }\end{array}$ & LongText & - & Cause of disease \\
\hline Treatment & LongText & - & Disease Solution \\
\hline Image & Varchar & 50 & Disease Image \\
\hline
\end{tabular}


3. Disease Symptoms

Table symptoms of disease serves to store data symptoms of the disease to the details in table 3.

Table 3. Symptoms Table

\begin{tabular}{|c|c|c|c|}
\hline Attribute & Type & Size & Description \\
\hline Id_symptoms & Int & 3 & Symptoms ID \\
\hline Disease & Varchar & 255 & Disease Name \\
\hline cf_expert & Double & - & CF Expert \\
\hline
\end{tabular}

4. User's Value

This data stores the symptom of user choice. Details are listed in table 4.

Table 4. Tabel User

\begin{tabular}{|c|c|c|c|}
\hline Attribute & Type & Size & Description \\
\hline Number & Int & 4 & Serial Number \\
\hline Id_symptoms & Int & 3 & Symptoms ID \\
\hline Description & Varchar & 100 & Description \\
\hline Value & Double & - & CF Value \\
\hline
\end{tabular}

5. Rule

Table rule or rule serves to store data base rules expert knowledge with the details in table 5.

Table 5. Rule's Table

\begin{tabular}{|c|c|c|c|}
\hline Attribute & Type & Size & Description \\
\hline Id_rule & Int & 3 & Rule ID \\
\hline Id_disease & Int & 4 & Disease ID \\
\hline Id_symptoms & Int & 3 & Symptoms ID \\
\hline
\end{tabular}

6. Rating Result

The assessment result table serves to store the results of the calculation by Certainty Factor (CF) method with the details in table 6 .

Table 6. Result's table

\begin{tabular}{|c|c|c|c|}
\hline Attribute & Type & Size & Description \\
\hline Id_disease & Int & 3 & Disease ID \\
\hline Name & Varchar & 75 & Disease Name \\
\hline CF & Double & - & CF Value \\
\hline
\end{tabular}

\subsection{System Interface}

Implementation of the system in accordance with the interface that has been designed previously, such as the initial menu in Figure 4. 


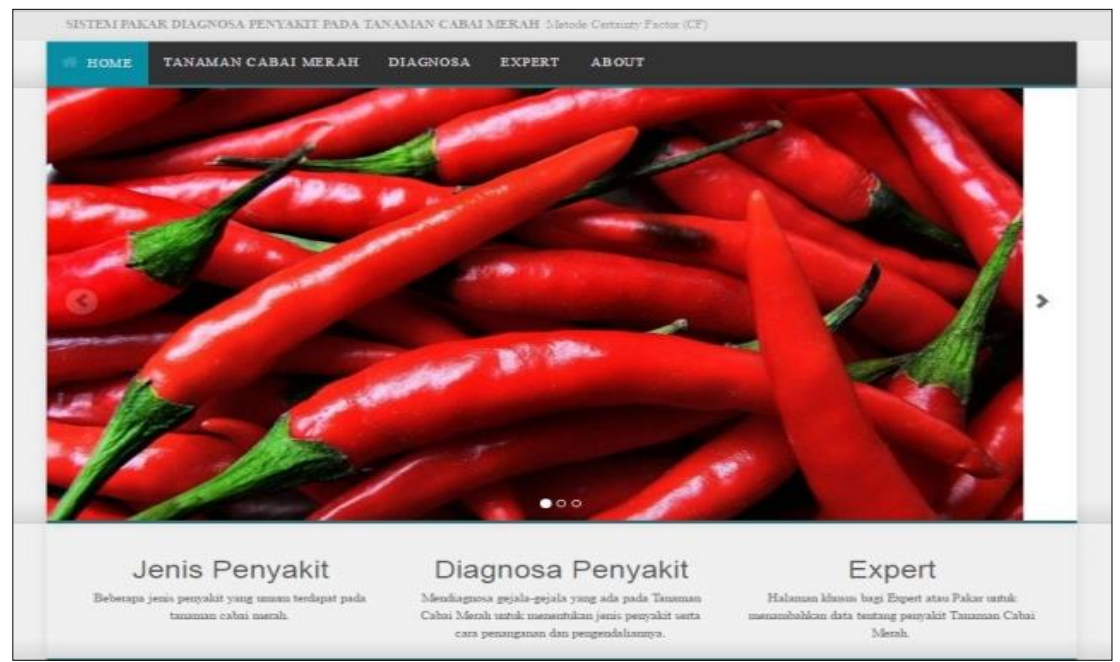

Figure 4. Preview Front Page

This menu is a menu or main form that contains various menu options that can access other menus desired. The main menu display on this diagnostic expert application of red chili diseases can be seen in Figure 5.

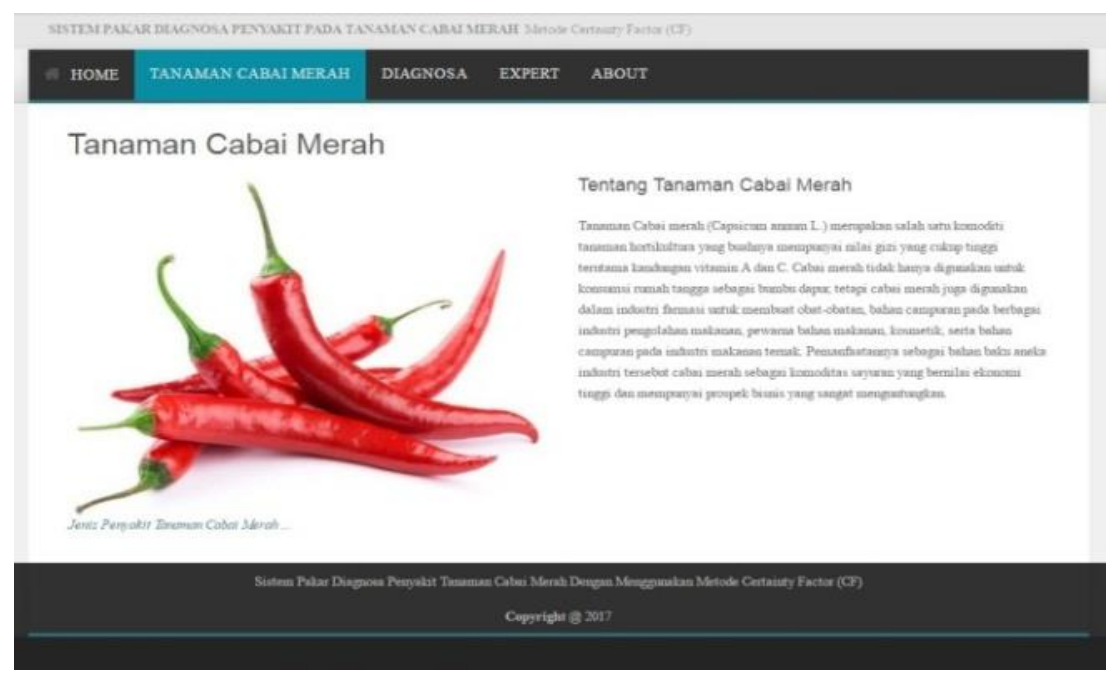

Figure 5. Preview the Plant of Red Pepper

This menu is a menu featuring a brief description of chilies, the benefits of chili and the types of diseases commonly experienced by red peppers. The explanation also comes with a picture. Display the diagnostic menu in Figure 6. 


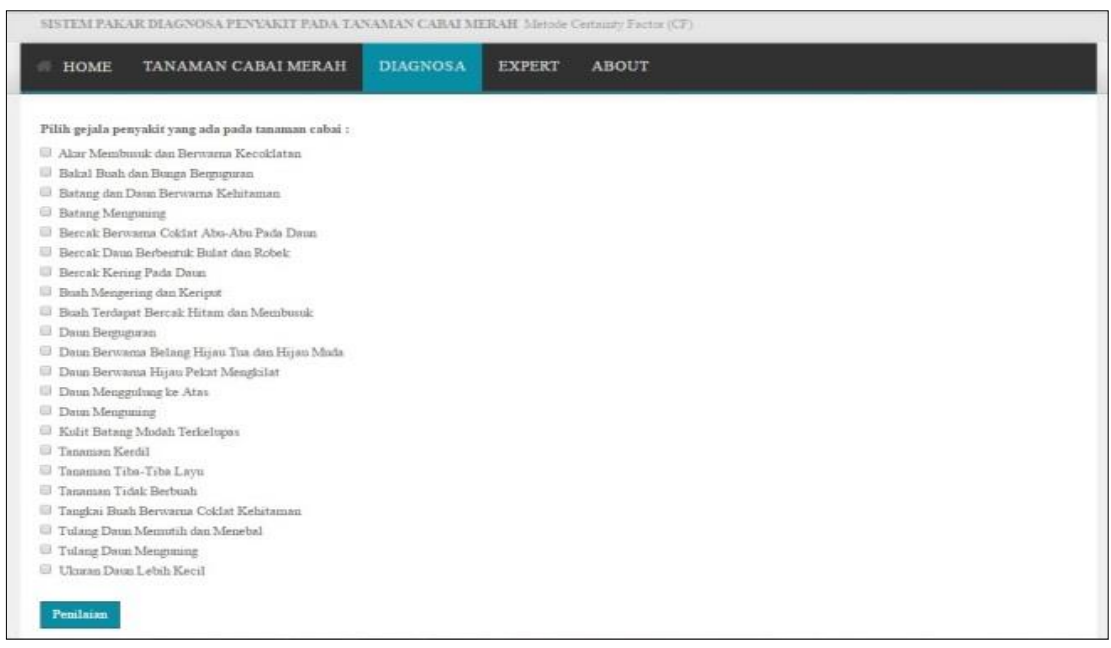

Figure 6. Preview the Diagnosis

Views of the user assessment page on this expert application of diagnosis of red chili diseases can be seen in Figure 7.

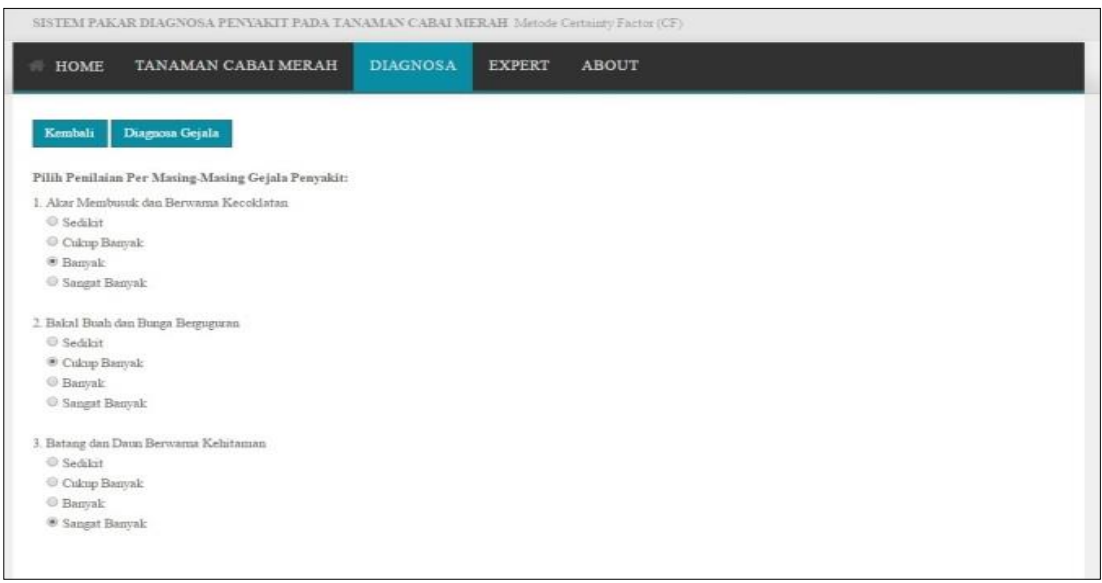

Figure 7. Preview User Assessment

Calculation of CF values in the application of expert system can be seen in Figure 8 .

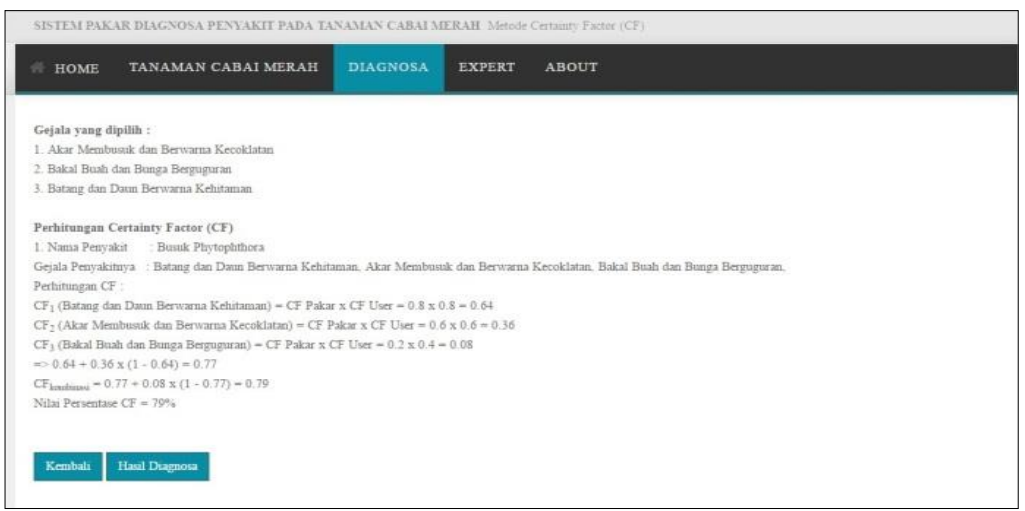

Figure 8. Preview CF Calculation 
The diagnosed page view on this expert system application of red pepper diagnosis can be seen in Figure 8. This page is used to display diagnostic and calculation results using Certainty Factor (CF) method by sorting from the largest value to the lowest value.

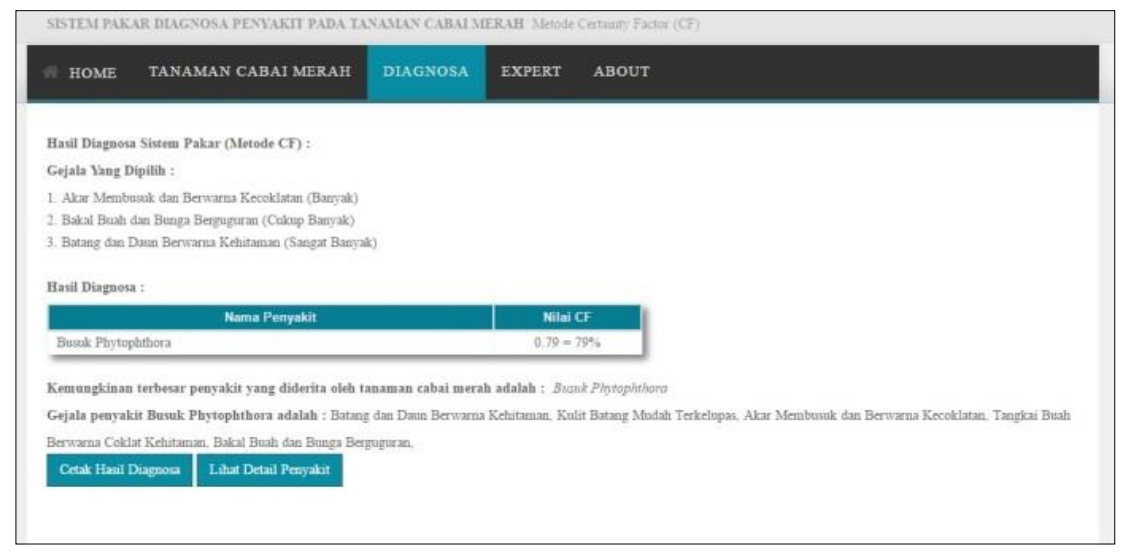

Figure 9. Preview Results of Diagnosis

\subsection{Testing Parameters}

Testing steps on this expert system are:

1. Knowledge Representation

This stage is the process of collecting data that is transformed from the knowledge of an expert and the literature related to the problems to be solved by expert systems diagnosis of red pepper disease.

The process of data collection followed by the process of data analysis that is by formulating data or knowledge that has been obtained to fit and can be used for the manufacture of expert systems diagnosis of red chili diseases. The process of collecting and analyzing the data is done in such a way as to produce rules (rules) to be used in the inference process. The results of the data collection that has been done will be presented in the form of tables.

This first part describes the list of chili diseases. The list of names of diseases is numbered. The list can be seen in table 7 .

Table 7. Name of Disease

\begin{tabular}{|l|l|}
\hline \multicolumn{1}{|c|}{ Code } & \multicolumn{1}{c|}{ Name of Disease } \\
\hline K001 & Antraknosa (Framboesia) \\
\hline K002 & Cercospora Leaves Patches \\
\hline K003 & Fusarium Withered \\
\hline K004 & Gemini Virus / Yellow Virus \\
\hline K005 & Phytophthora Foul \\
\hline K006 & Mosaic \\
\hline
\end{tabular}

After knowing the list of names of diseases, then in this section try to separate the symptoms of disease based on the name of the disease. The list of symptoms of the disease and its CF values can be seen in Table 8 to Table 13.

Table 8. Symptoms of Antraknosa (Framboesia)

\begin{tabular}{|c|c|c|c|}
\hline \multicolumn{2}{|c|}{ Code } & Name of Symptoms & CF \\
\hline \multirow{4}{*}{ K001 } & G09 & $\begin{array}{c}\text { Fruit have a black spot and } \\
\text { decaying }\end{array}$ & 0,8 \\
\cline { 2 - 4 } & G08 & Fruit dries and wrinkles & 0,6 \\
\cline { 2 - 4 } & G07 & Spotting dry on leaves & 0,6 \\
\cline { 2 - 4 } & G14 & Leaf yellowing & 0,4 \\
\cline { 2 - 4 } & G10 & Leaves dying & 0,2 \\
\hline
\end{tabular}


Table 9. Symptoms of Cercospora Leaves Patches

\begin{tabular}{|c|c|c|c|}
\hline \multicolumn{2}{|c|}{ Code } & Name of Symptoms & CF \\
\hline \multirow{4}{*}{ K002 } & G06 & $\begin{array}{c}\text { Spotting globular fronds and } \\
\text { torn }\end{array}$ & 0,8 \\
\cline { 2 - 4 } & G07 & Spotting dry on leaves & 0,6 \\
\cline { 2 - 4 } & G05 & Patches brown grey on leaves & 0,4 \\
\cline { 2 - 4 } & G12 & Green leaves and shiny & 0,2 \\
\cline { 2 - 4 } & G10 & Leaves dying & \\
\hline
\end{tabular}

Table 10. Symptoms of Fusarium Withered

\begin{tabular}{|c|c|c|c|}
\hline \multicolumn{2}{|c|}{ Code } & Name of Symptoms & CF \\
\hline \multirow{4}{*}{ K003 } & G17 & Plants suddenly withered & 0,8 \\
\cline { 2 - 4 } & G01 & Root rot and brownish color & 0,6 \\
\cline { 2 - 4 } & G14 & Leaf yellowing & 0,4 \\
\cline { 2 - 4 } & G20 & $\begin{array}{c}\text { The leaves whitened and } \\
\text { thicken }\end{array}$ & 0,2 \\
\hline
\end{tabular}

Table 11. Symptoms of Gemini Virus / Yellow Virus

\begin{tabular}{|c|c|c|c|}
\hline \multicolumn{2}{|c|}{ Code } & Name of Symptoms & CF \\
\hline \multirow{7}{*}{ K004 } & G04 & Stems yellowing & 0,8 \\
\cline { 2 - 4 } & G13 & Leaves roll to over & 0,6 \\
\cline { 2 - 4 } & G14 & Leaf yellowing & 0,4 \\
\cline { 2 - 4 } & G20 & $\begin{array}{c}\text { The leaves whitened and } \\
\text { thicken }\end{array}$ & 0,2 \\
\cline { 2 - 4 } & G16 & Dwarf plants & 0,2 \\
\cline { 2 - 4 } & G18 & Plants unfruitful & 0,2 \\
\hline
\end{tabular}

Table 12. Symptoms of Phytophthora Foul

\begin{tabular}{|c|c|c|c|}
\hline \multicolumn{2}{|c|}{ Code } & Name of Symptoms & CF \\
\hline \multirow{4}{*}{$* 4$} & G03 & $\begin{array}{c}\text { Stems and leaves dusky } \\
\text { colored }\end{array}$ & 0,8 \\
\cline { 2 - 4 } & $\mathrm{G} 15$ & The bark is easy flaky & 0,8 \\
\cline { 2 - 4 } & $\mathrm{G} 01$ & Root rot and brownish color & 0,6 \\
\cline { 2 - 4 } & $\mathrm{G} 19$ & $\begin{array}{c}\text { The stalk is blackish brown } \\
\text { color }\end{array}$ & 0,4 \\
\cline { 2 - 4 } & $\mathrm{G} 02$ & Fruit and flowers dying & 0,2 \\
\hline
\end{tabular}

Table 13. Symptoms of Mosaic

\begin{tabular}{|c|c|c|c|}
\hline \multicolumn{2}{|c|}{ Code } & Name of Symptoms & CF \\
\hline \multirow{4}{*}{ K006 } & G11 & $\begin{array}{c}\text { Leaves are dark green and } \\
\text { light green color }\end{array}$ & 0,8 \\
\cline { 2 - 4 } & $\mathrm{G} 22$ & Leaves size are smaller & 0,6 \\
\cline { 2 - 4 } & $\mathrm{G} 21$ & The leaves yellowing & 0,4 \\
\cline { 2 - 4 } & $\mathrm{G} 16$ & Dwarf plants & 0,2 \\
\hline
\end{tabular}

Data on the existing symptom table, can be abbreviated to the decision table whose contents or relationship between the symptoms and the name of the disease, can be seen in table 14 .

Table 14. Symptoms Relations

\begin{tabular}{|c|c|c|c|c|c|c|}
\hline \multirow{2}{*}{ ID } & \multicolumn{7}{|c|}{ ID of Disease } \\
\hline & K001 & K002 & K003 & K004 & K005 & K006 \\
\hline G01 & & & $\sqrt{ }$ & & $\mathrm{V}$ & \\
\hline G02 & & & & & $\mathrm{V}$ & \\
\hline G03 & & & & & $\checkmark$ & \\
\hline G04 & & & & $\mathrm{V}$ & & \\
\hline
\end{tabular}




\begin{tabular}{|c|c|c|c|c|c|c|}
\hline G05 & & $v$ & & & & \\
\hline G06 & & $v$ & & & & \\
\hline G07 & v & $v$ & & & & \\
\hline G08 & v & & & & & \\
\hline G09 & $v$ & & & & & \\
\hline G10 & $v$ & $v$ & & & & \\
\hline G11 & & & & & & $v$ \\
\hline G12 & & $v$ & & & & \\
\hline G13 & & & & $v$ & & \\
\hline G14 & $v$ & & $v$ & $v$ & & \\
\hline G15 & & & & & $v$ & \\
\hline G16 & & & & $v$ & & $v$ \\
\hline G17 & & & $v$ & & & \\
\hline G18 & & & & $v$ & & \\
\hline G19 & & & & & $v$ & \\
\hline G20 & & & $v$ & $v$ & & \\
\hline G21 & & & & & & $v$ \\
\hline G22 & & & & & & $v$ \\
\hline
\end{tabular}

Furthermore from each type of disease described the cause of the disease and also the solution handling.

2. Completion of Case using Certainty Factor Method (CF)

Calculation of Certainty Factor method can be seen in this explanation. The first step is to choose the appropriate disease symptoms or experienced by red peppers. The symptoms of the disease selected can be seen in table 15 .

Table 15. Chosen Symptoms

\begin{tabular}{|c|l|c|}
\hline No & \multicolumn{1}{|c|}{ Symptoms of Disease } & CF \\
\hline G01 & Root rot and brownish color & 0,6 \\
\hline G02 & Fruit and flowers dying & 0,2 \\
\hline G03 & Stems and leaves dusky colored & 0,8 \\
\hline
\end{tabular}

The second step is to determine the weight of the value (CF) of the user in accordance with the category of choice that has been selected by the user as in table 16 .

Table 16. CF user

\begin{tabular}{|c|l|c|}
\hline No & \multicolumn{1}{|c|}{ Symptoms } & CF \\
\hline G01 & So Much & 0,4 \\
\hline G02 & Many & 0,6 \\
\hline G03 & Very Much & 0,8 \\
\hline
\end{tabular}

The next step calculates the CF value by multiplying the CF value of the user with the Expert CF value.

$\mathrm{CF}[\mathrm{H}, \mathrm{E}]_{\mathrm{n}}=\mathrm{CF}[\mathrm{H}] * \mathrm{CF}[\mathrm{E}]$

1) CF value for "Root rot and brownish color"

$$
\begin{aligned}
\mathrm{CF}_{1} & =\mathrm{CF}[\mathrm{H}]_{1} * \mathrm{CF}[\mathrm{E}]_{1} \\
& =0,6 * 0,4 \\
& =0,24
\end{aligned}
$$

2) CF value for "Fruit and flowers dying"

$\mathrm{CF}_{2}=\mathrm{CF}[\mathrm{H}]_{2} * \mathrm{CF}[\mathrm{E}]_{2}$

$=0,2 * 0,6$ 


$$
=0,12
$$

3) CF value for "Stems and leaves dusky colored"

$$
\begin{aligned}
\mathrm{CF}_{3} & =\mathrm{CF}[\mathrm{H}]_{3} * \mathrm{CF}[\mathrm{E}]_{3} \\
& =0,8 * 0,8 \\
& =0,64
\end{aligned}
$$

The next step combines the $\mathrm{CF}$ values for each of the created rules.

$\mathrm{CF}_{\text {combine }} \mathrm{CF}[\mathrm{H}, \mathrm{E}]_{1,2}=\mathrm{CF}[\mathrm{H}, \mathrm{E}]_{1}+\mathrm{CF}[\mathrm{H}, \mathrm{E}]_{2} *\left(1-\mathrm{CF}[\mathrm{H}, \mathrm{E}]_{1}\right)$

Cfcombine for phytophthora foul disease Symptoms of phytophthora foul disease are root rot and brownish $\left(\mathrm{CF}_{1}\right)$, will fruits and flowers fall $\left(\mathrm{CF}_{2}\right)$ and stems and blackish-colored $\left(\mathrm{CF}_{3}\right)$.

$$
\begin{aligned}
\mathrm{CF}[\mathrm{H}, \mathrm{E}]_{1,2} & =\mathrm{CF}[\mathrm{H}, \mathrm{E}]_{1}+\mathrm{CF}[\mathrm{H}, \mathrm{E}]_{2} *\left(1-\mathrm{CF}[\mathrm{H}, \mathrm{E}]_{1}\right) \\
& =0,24+0,12(1-0,24) \\
& =0,33 \\
\mathrm{CF}[\mathrm{H}, \mathrm{E}]_{2,3}= & \mathrm{CF}[\mathrm{H}, \mathrm{E}]_{1,2}+\mathrm{CF}[\mathrm{H}, \mathrm{E}]_{3} *\left(1-\mathrm{CF}[\mathrm{H}, \mathrm{E}]_{1,2}\right) \\
& =0,33+0,64(1-0,33) \\
& =0,758 \\
& =76 \%
\end{aligned}
$$

After calculated the value of CF combination it can be concluded the percentage of the largest CF value for the name of the disease in accordance with the rulenya, namely: phytophthora rot disease $=76 \%$. So from the symptoms of the disease is selected root rot and brownish, will fruit and flowers falling, stems and leaves blackish THEN illness suffered is phytophtora rot disease (76\%).

\section{CONCLUSION}

\subsection{Conclusion}

The results of this study produce some conclusions, namely:

1. Expert System Diagnosing Red Chili Disease Using Certainty Factor method has been built in accordance with the design and can be used as a recommendation farmers in diagnosing red pepper disease.

2. Have built expert system diagnosis of red pepper disease can show the type of disease suffered by chili based on symptoms of disease selected.

3. The Certainty Factor method is influenced by the assessment of the User and the experts themselves, therefore fewer of the symptoms are selected the less percentage of diseases assessed.

4. The Certainty Factor (CF) method can be applied to expert systems to provide solutions that match the symptoms of illness suffered by red peppers based on system test results.

\subsection{Suggestions}

Some suggestions are useful in the development of advanced systems among others:

1. It is expected that the development of this application includes more types of diseases in other horticultural crops.

2. It is expected that the application can be developed not only through the website but can also through a smartphone or tablet to facilitate users to access the application.

3. It is expected to add more symptoms of disease data to chili plants, ranging from the infected pest and virus congenital pepper seeds.

4. Can be developed with other methods in order to produce a good level of accuracy. 


\section{REFERENCES}

[1] Cahyono, B. 2014. Rahasia Budidaya Cabai Merah Besar \& Keriting Secara Organik dan Anorganik. Jakarta: Pustaka Mina.

[2] Cakrabawa. 2013. Buletin Konsumsi Pangan. Jakarta Selatan: Pusat Data dan Sistem Informasi Pertanian.

[3] Ali, M,A. 2015. Pemodelan Sistem Pakar Diagnosa Penyakit Tanaman Cabai Menggunakan Metode AHP-SAW. Malang: Universitas Brawijaya.

[4] Tuswanto, 2013. Sistem Pakar Untuk Mendiagnosa Hama dan Penyakit Tanaman Bawang Merah Menggunakan Certainty Factor. Universitas Ahmad Dahlan.

[5] Andri Saputra, H.A.T., 1978. Sistem Pakar Kerusakan Mesin Jahit Dengan Metode Certainty Factor Berbasis Android. Journal Of Applied Intelligent System, Vol.1, No. 1, Februari 2016 pp.36-47.

[6] Kusumadewi, S. 2003. Artificial Intelegence. Yogyakarta: Andi.

[7] Aziz, F. 1994. Belajar sendiri Pemrograman Sistem Pakar, Jakarta: Elex Media Komputindo.

[8] Turban, 2005. Dessicion Support System and Intelligent System. Yogyakarta: Andi.

[9] Arhami, M. 2005. Konsep Dasar Sistem Pakar, Yogyakarta: Andi.

[10] Kusrini. 2008. Sistem Pakar Teori Dan Aplikasi. Yogyakarta: Andi.

[11] Alex, S. 2015. Usaha Tani Cabai Kiat Jitu Bertanam Cabai di Segala Musim. Yogyakarta: Pustaka Baru Press.

[12] Surachman. E, 2007. Hama Tanaman. Yogyakarta: Penerbit Kanisius.

[13] Suryanto. W, 2010. Hama dan Penyakit Tanaman Pangan, Hortikultura, dan Perkebunan. Yogyakarta: Penerbit Kanisius

[14] Irwanto. 2005. Perancangan Object Oriented Software dengan UML. Yogyakarta: Andi.

[15] Nugroho, A. 2009, Rekayasa Perangkat Lunak menggunakan UML dan Java, Andi Offset, Yogyakarta: Andi.

[16] Fowler, M. 2004. UML. Distilled.Edisi ke-3. Terjemahan Tim Penerjemah Penerbit Andi. Yogyakarta: Andi. 